\title{
Biological Performance of Certain Agrochemicals and IPM Program against Leafminers, Liromyza trifolii Burg on the Garden Bean
}

\author{
Saad, A. S. A. ${ }^{1}$, H. A. Mesbah ${ }^{1}$, A. M. Kordy ${ }^{1}$ and M. Khames ${ }^{1}$
}

\begin{abstract}
The present study was carried out at a private farm cultivated with garden $\backslash$ bean (Phaseolus vulgaris) var. Nepraska during the subsequent Neely seasons of 2014, 2015 and 2016 to control the leafminer, liromyza trifolii Burg at El-Nahada region, Alexandria Governorate, Egypt.

In the first season of 2014, Chlorantraniliprole and Abamectin were the most effective treatments against the leafminer, liromyza trifolii Burg corresponding to percent reduction of 90.98 and 64.04 , followed by Acetampride $55.60 \%$ and Thiamethoxam- $48.30 \%$. The least effective agrochemicals were Lambda cyhalothrin- $27.96 \%$, Azadirachtin- 25.55\% and Detergent- 12.58\%.

On 2015 season, the data comfirmed that the most efficient Chlorantraniliprole $\mathbf{7 7 . 0 7 \%}$ and Abamectin $64.13 \%$ followed by Acetampride and Thiamethoxam $48.56 \%$ and $38.94 \%$, in successively. The least effective agrochemicals were Azadirachtin 29.18\%, Lambda cyhalothrin $\mathbf{2 4 . 7 1 \%}$ and Detergent $\mathbf{9 . 3 2} \%$, respectively.

On 2016 season, the IPM model showed that the best treatment was abamectin followed by acetamprid, chlorantraniliprole and thiamethoxam while the least treatments were lambda cyhalothrin, azadirachtin and detergent.
\end{abstract}

Key words: Garden bean (Phaseolus vulgaris), the leafminers, liromyza trifolii Burg and total yield.

\section{INTRODUCTION}

The legume plants are considered a good source for protein. The garden bean, (Phasealus vulgaris L.) is one of the important vegetable crops in Egypt for both local as well as export markets. Garden bean is one of the main sources for protein. It is valuable for its richness in the amine acids lysine and tryptophan that are lacking in cereals and other foods (Karel and Mghogho, 1985). In Egypt garden bean is cultivated in area over than 41012 feddans for green pods production and 21533 feddans for dry seeds production, which produced about 167276 tons green pods and 29634 tons for seeds (according to the Bulletin of Agriculture statistics, Part 2, (Summer, Neely crops, and fruit), Ministry of Agriculture, Egypt, 2011).

This crop is grown in the open field in two main seasons i.e. spring and autumn, the autumn crop ends at the beginning of January and spring crop start at the beginning of April. Therefore, a gap of three months exists, i.e January, February and March with minimum production of garden bean in Egypt and in several Mediterranean countries due to the low temperature prevailing during this period at year. For instance, Temperature falls to less than $7^{\circ} \mathrm{c}$ at night in January and February in Egypt. The demand for export of the Egyptian garden beans is located in the winter season. The production of garden beans is affected by factors such as rain fall, temperature, time of planting, plant density, soil fertilizer, insect infestations and diseases infection (Barakat, 2007, Mesbah et al., 2011). Garden beans, Phaseolus vulgaris plants are attacked by different insect pests some of these are aphid, whitefly, trips, gassed, spiders' mite and leafminers that infest leaves of Phaseolus vulgaris. Apart from them the leafminers, liromyza trifolii Burg (Lepidoptera: Agromyzide) which under this study.

Leaf miner (liromyza trifolii Burg.) is serious pest of vegetable crops and ornamental plants worldwide. Injury is resulted when adult females puncture leaves for feeding, or oviposition and also when offspring larvae from serpentine mines (Parella et al., 1985). These white tunnels interfere with the photosynthetic process, thus delaying crop development and decreasing the yield.

Integrated Pest Management (IPM) is a pest control strategy that uses a multitude of techniques to bring about effective, economic control of diseases, insects, nematodes, and weeds in snap bean fields. These techniques include cultural methods, resistant varieties, biological control, and use of chemicals (Barakat, 2007, Mesbah et al., 2016).

Because of the rapid increase and spread of leafminers, growers have frequently applied large quantities of insecticides belonging to different chemical groups, some of which are evidently harmful for the beneficial insects. In addition, the applications of broad spectrum insecticides have resulted in a decrease of parasitoids abundance in the vegetable fields and an increase in the development of pesticide resistance within the fly populations, followed by an increase in leafminers density (Johansen et al., 2003).

Therefore, the aim of the present study was focused on this insect pest that attacking in the field at different time of cultivations concerning with the leafminers. Also, the study evaluated some treatments as solely or in

${ }^{1}$ Plant Protection Dept., Faculty of Agric. (Saba Basha),

Alex. Univ., Egypt

Received February 15, 2017, Accepted March 28, 2017 
mixtures for controlling the leaf miners on this insect pest and to evaluate their efficacy on this harmful insect to be involved to an integrated pest management program "IPM".

\section{MATERIALS AND METHODS}

\section{Experimental design:}

The field trials were carried out in a private farm in El-Nahada region, $25 \mathrm{Km}$ south west of Alexandria, cultivated with garden bean (Phaseolus vulgaris) var. Nepraska during the neely season of 2014, 2015 and 2016. The seeds were sown on $3^{\text {rd }}$ September in both seasons.

The selected farm is divided into many longitudinal blocks separated by buffer paths of $1 \mathrm{~m}$ to prevent insecticides drift. The plants were grown along distance of $15-20 \mathrm{~cm}$ apart and in rows of $50 \mathrm{~cm}$ width. The experimental area where treated according to the normal agricultural practices and recommendation guidance.

\section{Chemicals used:}

1. Abamectin (Vertemic 1.8\% EC) ${ }^{\circledR}$

2. Acetamiprid (Mospilan 20\% SP) ${ }^{\circledR}$

3. Thiamethoxam (Actara $25 \% \mathrm{WG})^{\circledR}$

4. Chlorantraniliprole $\left(\right.$ Coragen ${ }^{\circledR} 20 \%$ SC) ${ }^{\circledR}$

5. Azadirachtin (Achock 0.15\% EC) ${ }^{\circledR}$

6. Lambda-Cyhalothrin (Halothrin Chema $2.5 \%$ EC) ${ }^{\circledR}$

7. Detergent (Potassy soap) ${ }^{\circledR}$

8. Mineral oil (kz oil $98 \%)^{\circledR}$

\section{Field experiments:}

To evaluate the performance of the tested insecticides on the incidence of insect-pest population, plants were sprayed with those suggested compounds to show to what extent they might be included in an IPM program of garden beans. Treatments included the application of seven compounds plus an untreated control check. Chemicals were applied with knapsack sprayer (20 1) (200 liter water / feddan). The compounds were applied according to the recommended dose of the
Egyptian Ministry of Agriculture for the control of the targeted pest. Two rows were used as a barrier between each treatment to avoid any interference of spray drift and therefore, the sampled plants would be away from each other. The evaluated chemicals with their rates of applications were shown in Table (a).

The garden bean plants received just one application of each tested compounds in both the neely season 2014, 2015 and 2016. These applications were carried out with their recommended doses against leafminers, L. trifolii during the vegetative growth, after 45 days from cultivation. Treatments of the garden bean plants were carried out by using some compounds such as Abamectin, Acetamprid, Azadirachtin, Chlorantraniliprole, Lambda cyhalothrin, Detergent, Thaimethoxam and mineral oil.

\section{Sampling technique:}

5 plants were taken random way from each plot (replicate) before spraying (15 plants / treatment) and after 1, 3, 5, 7 and 10 days after spraying. In each plot (replicate) for calculating the reduction percentage the number of larvae per sampled plant was recorded

\section{Calculation of the infestation reduction:}

Pre and post treatment application after 1, 3, 5, 7 and 10 days, the percentages of infestation reduction were calculated according to Henderson and Tilton's equation, 1955 as follows:

$$
\text { Reduction \% }=1-\quad \frac{\mathrm{A}}{\mathrm{B}} \times \frac{\mathrm{C}}{\mathrm{D}} \times 100
$$

Where:

$A=$ Mean No. of larvae in treatment after spraying.

$\mathrm{B}=$ Mean No. of larvae in treatment before spraying.

$\mathrm{C}=$ Mean No. of larvae in untreated check (control) before spraying.

$\mathrm{D}=$ Mean No. of larvae in untreated check (control) after spraying.

Table a. The agrochemicals and the rates of applications during experimental seasons of 2014, 2015 and 2016.

\begin{tabular}{lll}
\hline Trade name & Common name & Application rate \\
Vertemic $1.8 \%{ }^{\circledR} \mathrm{EC}$ & Abamectin & $100 \mathrm{cc} /$ Feddan \\
Mospilan $20 \%{ }^{\circledR} \mathrm{SP}$ & Acetamprid & $50 \mathrm{~g} / \mathrm{Feddan}$ \\
Achock $0.15 \%{ }^{\circledR} \mathrm{EC}$ & Azadirachtin & $400 \mathrm{cc} / \mathrm{Feddan}$ \\
Coragen $20 \%{ }^{\circledR} \mathrm{SC}$ & Chlorantraniliprole & $60 \mathrm{cc} / \mathrm{Feddan}$ \\
Halothrin Chema $2.5 \%{ }^{\circledR} \mathrm{EC}$ & Lambda cyhalothrin & $250 \mathrm{cc} / \mathrm{Feddan}$ \\
Potassy soap ${ }^{\circledR}$ & Detergent & $1000 \mathrm{cc} / \mathrm{Feddan}$ \\
Actara $25 \%{ }^{\circledR} \mathrm{WG}$ & Thaimethoxam & $50 \mathrm{~g} / \mathrm{Feddan}$ \\
$\mathrm{kz}$ oil $98 \%{ }^{\circledR}$ & Mineral oil & $3 \mathrm{~L} / \mathrm{Feddan}$ \\
\hline
\end{tabular}

$\mathrm{EC}=$ Emulsifiable Concentration, $\mathrm{SP}=$ Sellable Powder, $\mathrm{Sc}=$ Suspension Concentration and $\mathrm{WG}=$ Granules or Tablets Water Dispersible 


\section{Statistical analysis:}

Data were subjected to the analysis of variance test (ANOVA) as randomized complete block design. The least significant differences (LSD) at the 5\% level were determined using a computer program (Costat) and Duncan's Multiple Range testes modified by Steel and Torrie, 1981 and LSD values were used to compare the mean numbers of inspected pest infestation.

\section{RESULTS and DISCUSSION}

The performance of different evaluated Agrochemical against the inspected leaf miner (Liriomyza trifolii) during the subsequent neely (Seasons of 2014 and 2015) on the garden beans (Phaseolus vulgaris)

It is obvious that the results in Table (1) and Fig. (1) showed that Chlorantraniliprole was significant more effective and represents the highest general means of reduction [ 90.98\%] followed by abamectin [64.04\%], Acetampride [55.60\%] and Thiamethoxam [ 48.30\%]. The least effective were corresponded to Lambda cyhalothrin[ 27.96\%], Azadirachtin[ 25.55\%] and Detergent [12.58\%].

In the second neely season of 2015 , the same trend was confined Chlorantraniliprole gave [77.07\%] followed by Abamectin [64.13\%] Acetampride [48.56\%] and Thiamethoxam [38.94\%]. The least effective results were obtained by Azadirachtin [29.18\%], Lambda cyhalothrin [24.71\%] and Detergent [9.32\%], (Table, 2 and Fig. 2).
In fact these findings of results agree to a great extent with those obtained by Leibee (1988) who reported that abamectin was very effective against larvae of Liriomyza trifolii under laboratory conditions. Kotb (2000) stated that abamectin was effective against the leafminer, L. trifolii. Abd El-Zaher (2005) confirmed that abamectin was effective against the leafminer, $L$. trifolii giving $77.57 \%$ reduction in neely season of 2004. In addition he stated that Detergent and Lambada cyhalothrin would not be recommended to be involved in a chemical program for controlling the leafminer, $L$. trifolii of the garden bean. Therefore, it is calculated that Chlorantraniliprole, abamectin and Acetamprid are good candidates to be included in an integrated pest management (IPM) program in leafminer, L. trifolii.

Biological performance of different adopted models for the tested chemical insecticides against the leaf miners (Liriomyza trifolii) during neely Seasons 2016 infesting the garden beans (Phaseolus vulgaris)

The results in Tables 3, 4 and 5 and Figs. 3, 4 and 5 showed that the efficiency of the tested insecticides through the different adopted models against the insectpest compared to the untreated check

Table, (3) and illustrated in Fig. (3) proved that that there were significant difference regarding the general mean of reduction percentages among the tested treatments. In this context, the highest general means of reduction resulted from abamectin 68.96. Meanwhile both of acetamprid and lambda cyhalothrin gave reduced values of reduction comparised $47.88,47.78 \%$ in respects. Table, (3)

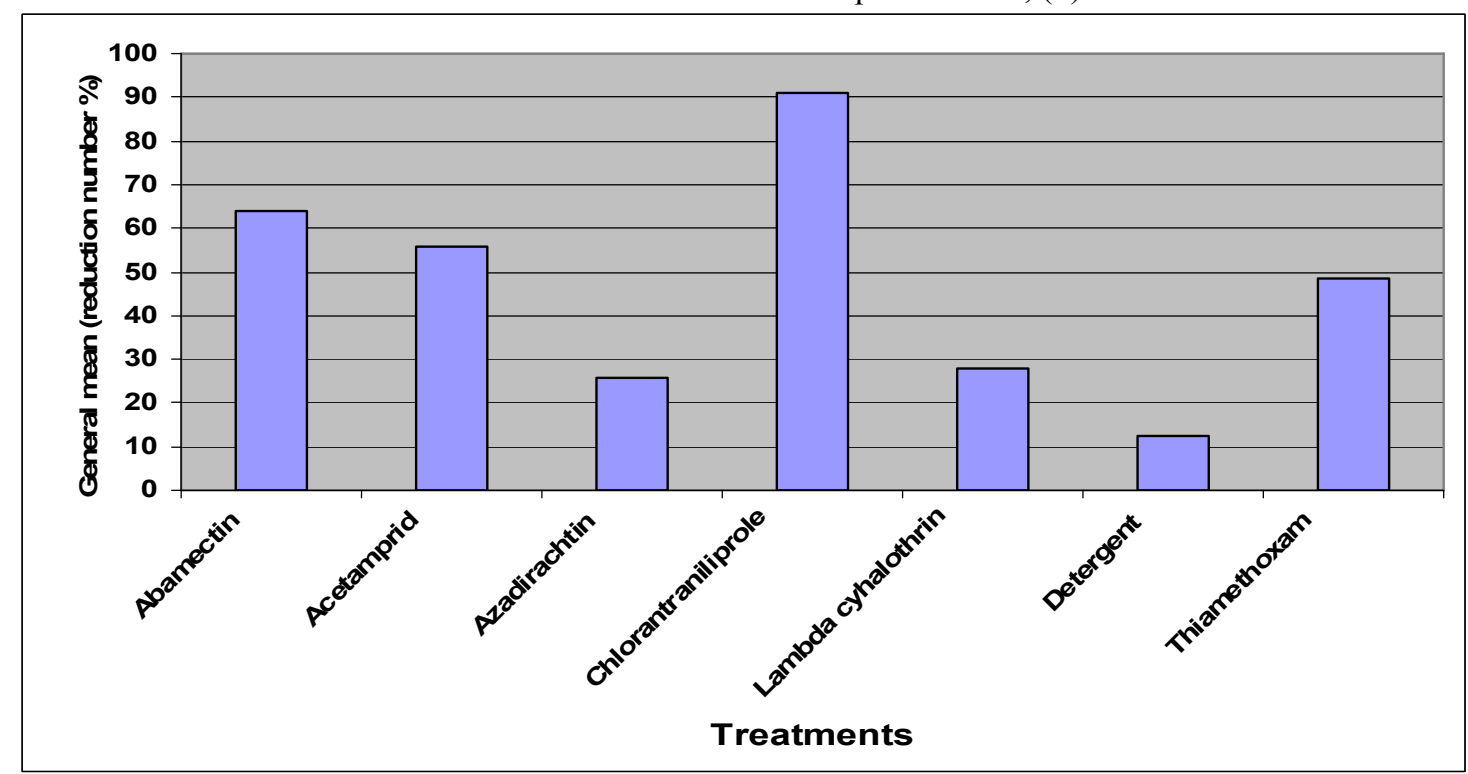

Fig. 1. Efficiency of tested compounds against Liriomyza trifolii infesting Phaseolus vulgaris (Nepraska cv.) in neely cultivation of the season 2014 . 


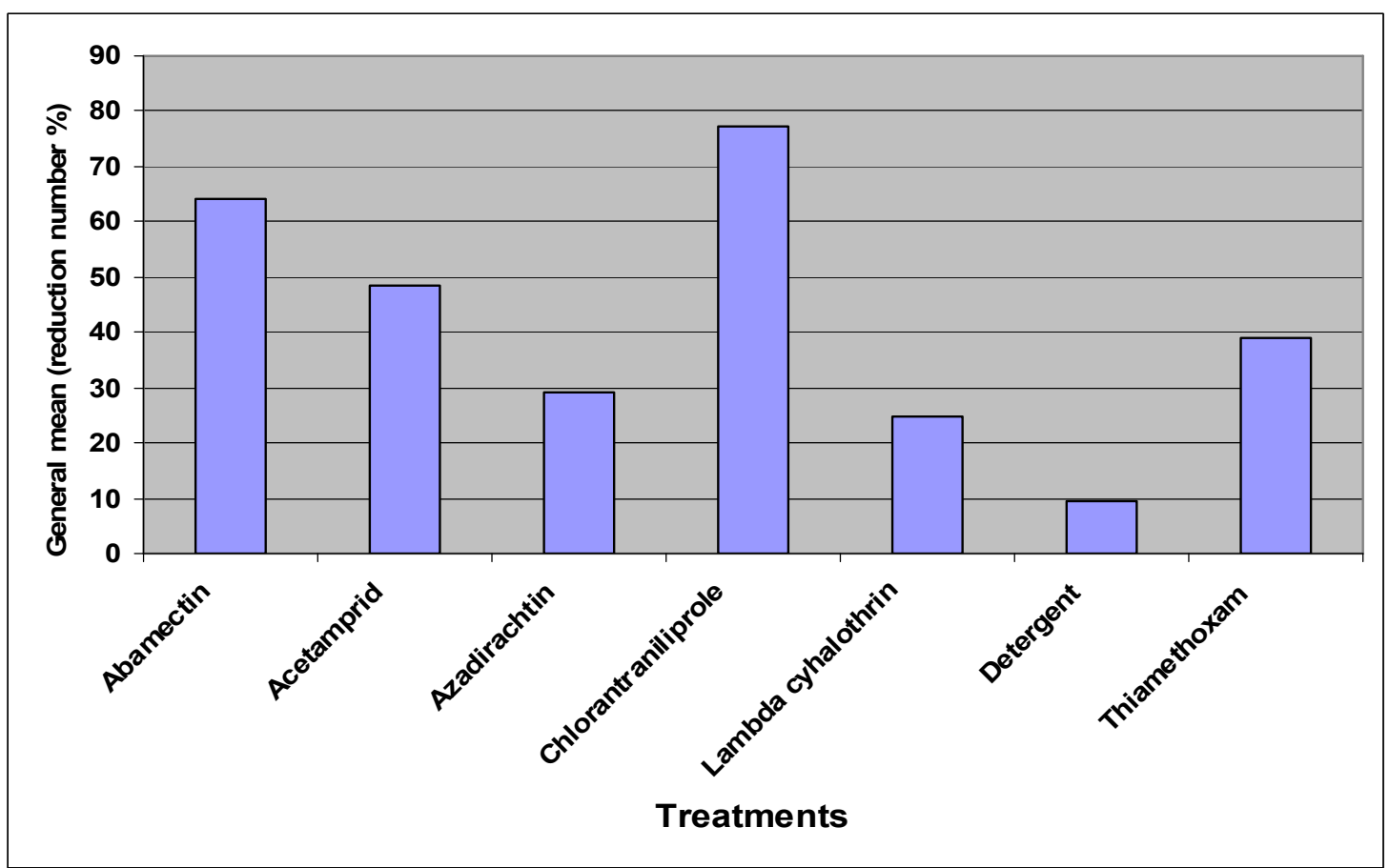

Fig. 2. Efficiency of tested compounds against Liriomyza trifolii infesting Phaseolus vulgaris (Nepraska cv.) in neely cultivation of the season 2015 .

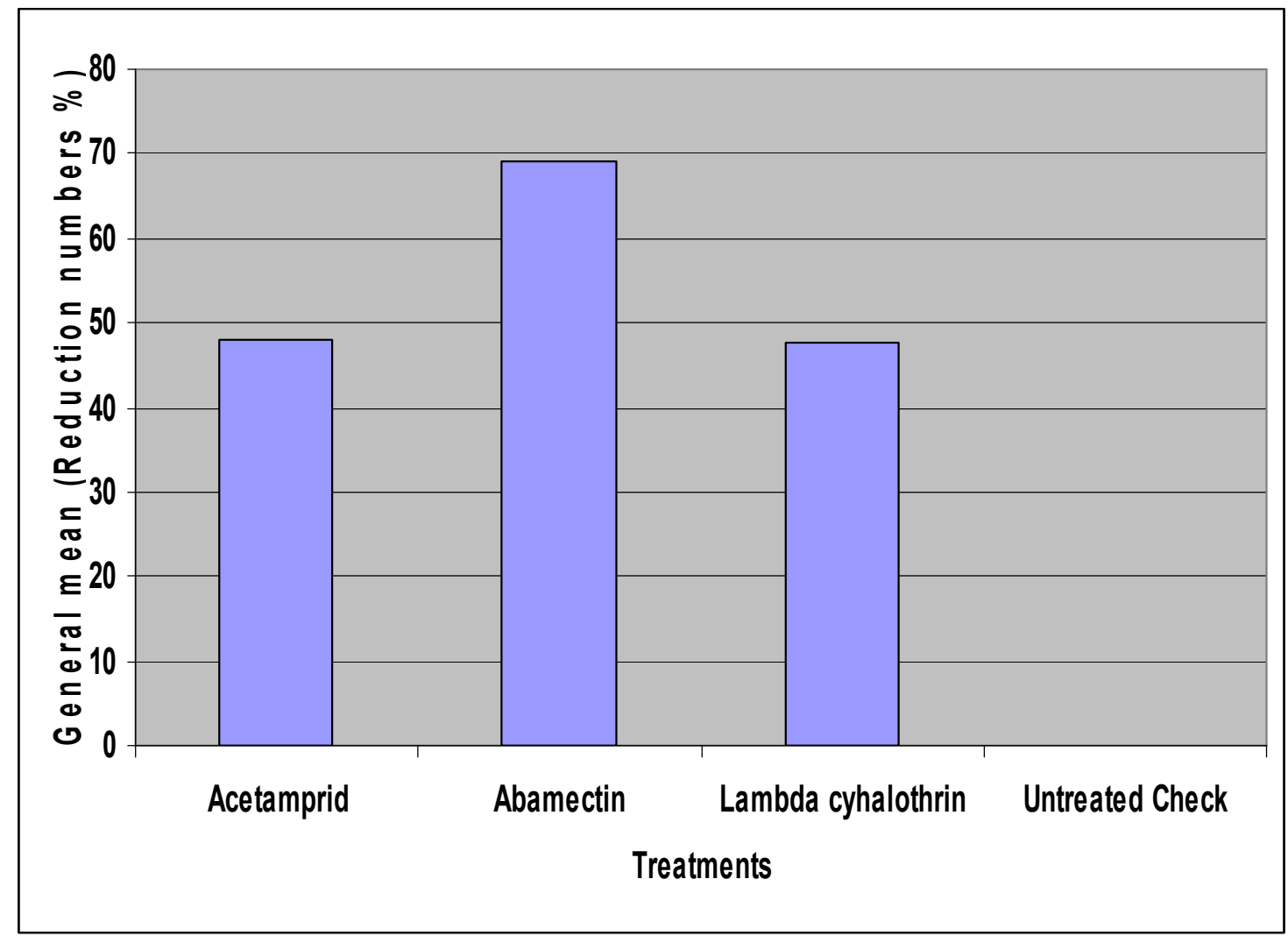

Fig. 3. Efficiency of tested pesticides against $L$. trifolii infesting Phasolus vulgaris leaflets in in neely cultivation of the season 2016. 


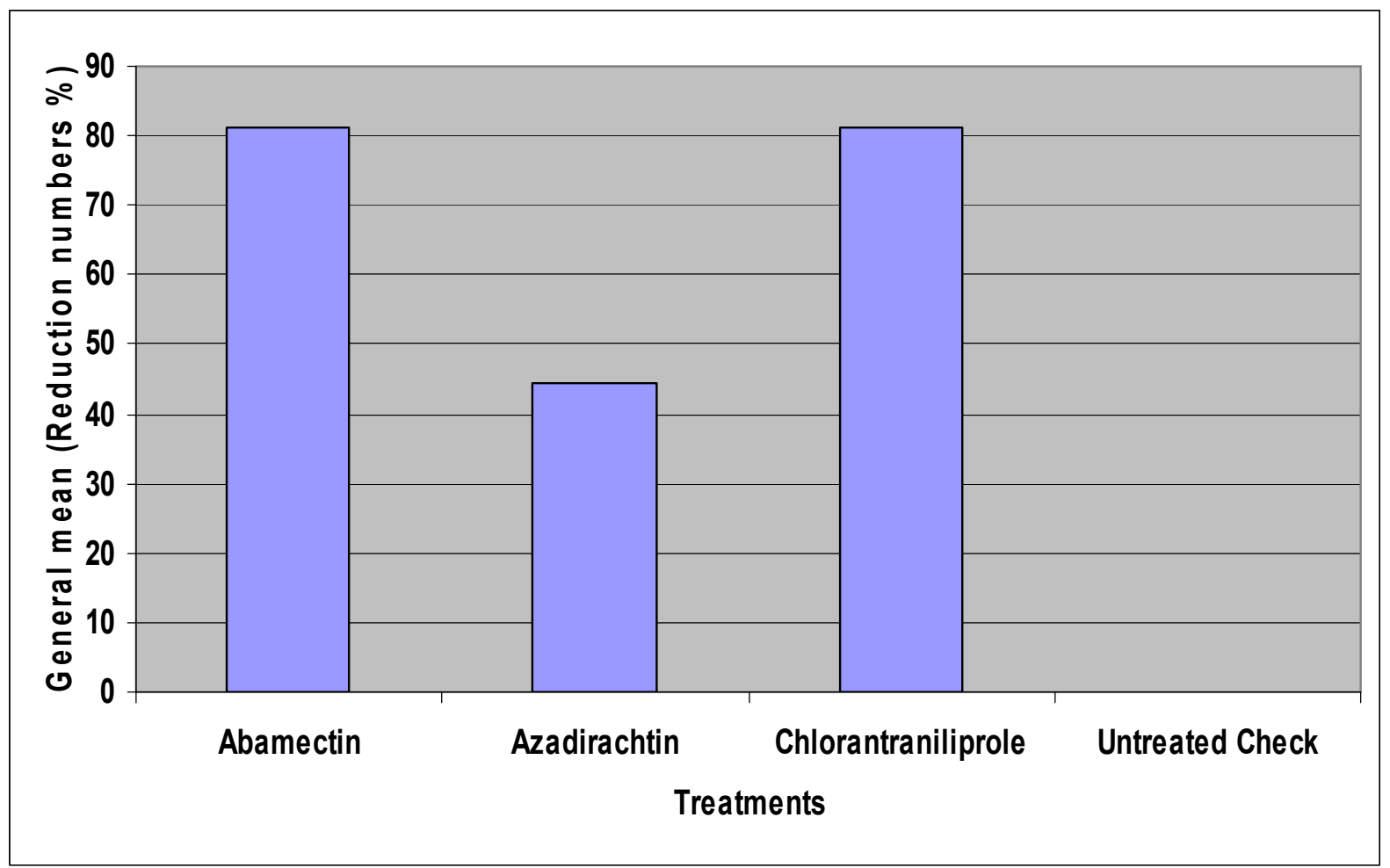

Fig. 4. Efficiency of tested pesticides against $L$. trifolii infesting Phasolus vulgaris leaflets in in neely cultivation of the season 2016.

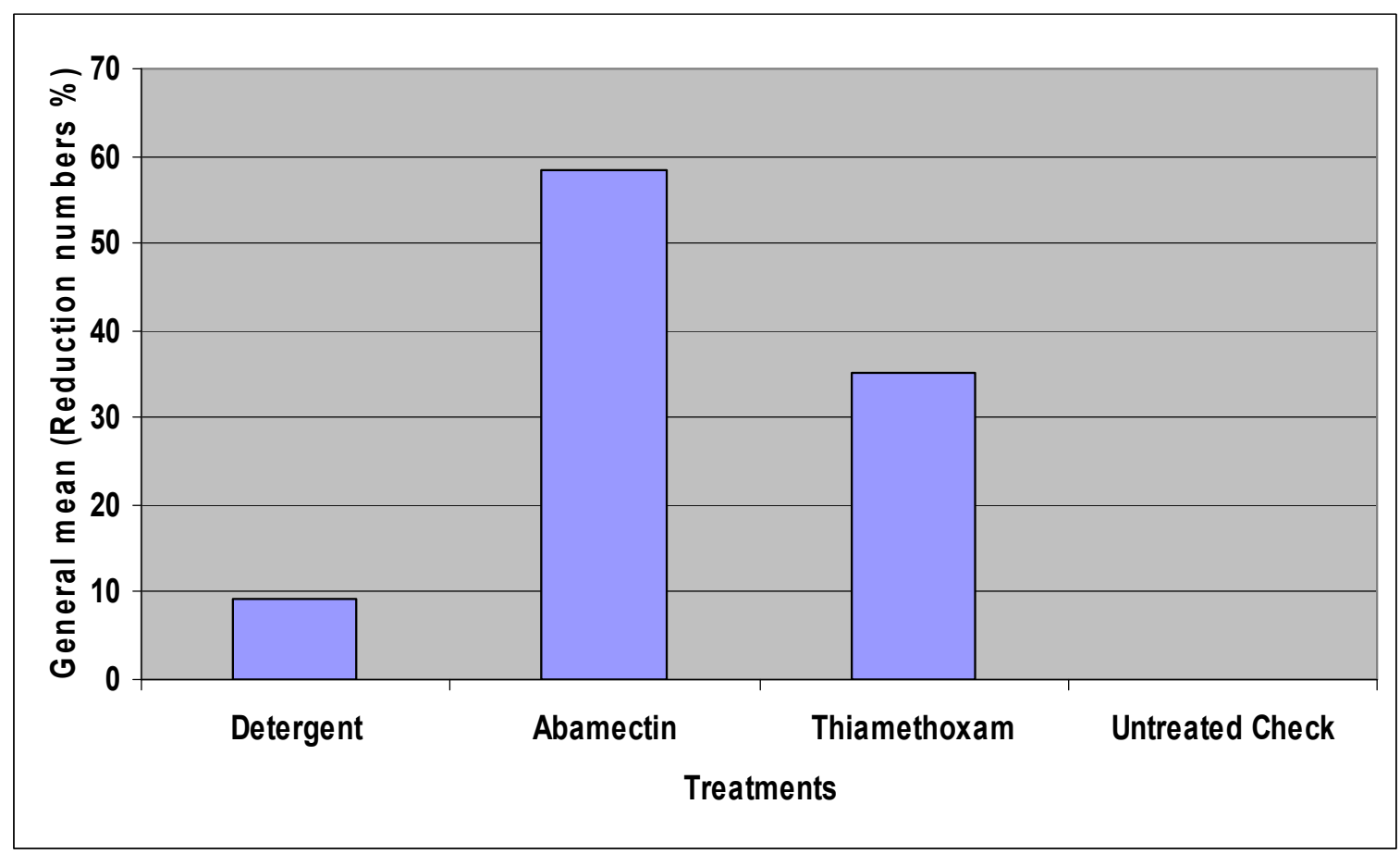

Figure 5. efficiency of tested pesticides against $L$. trifolii infesting Phasolus vulgaris leaflets in in neely cultivation of the season 2016. 


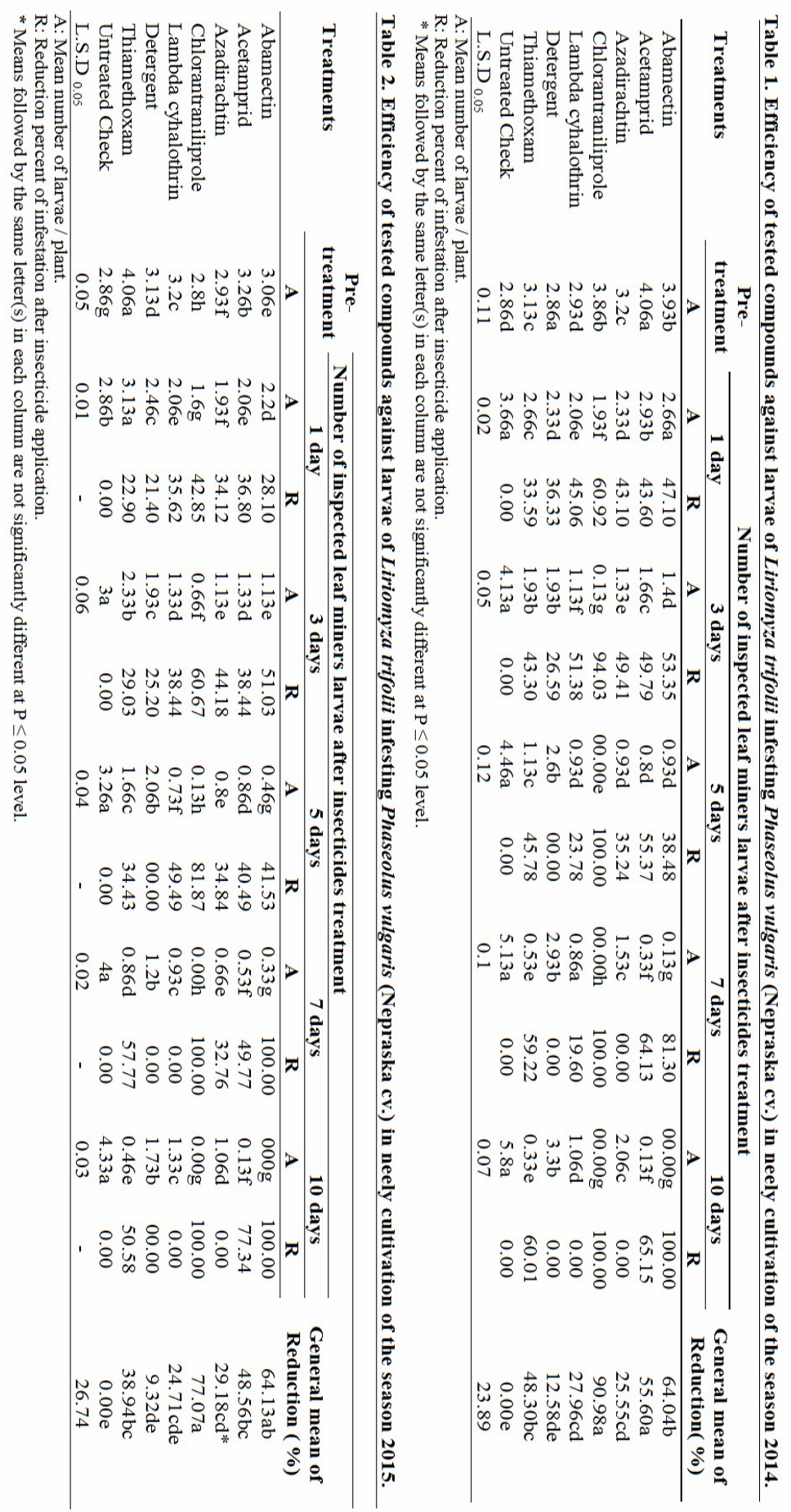




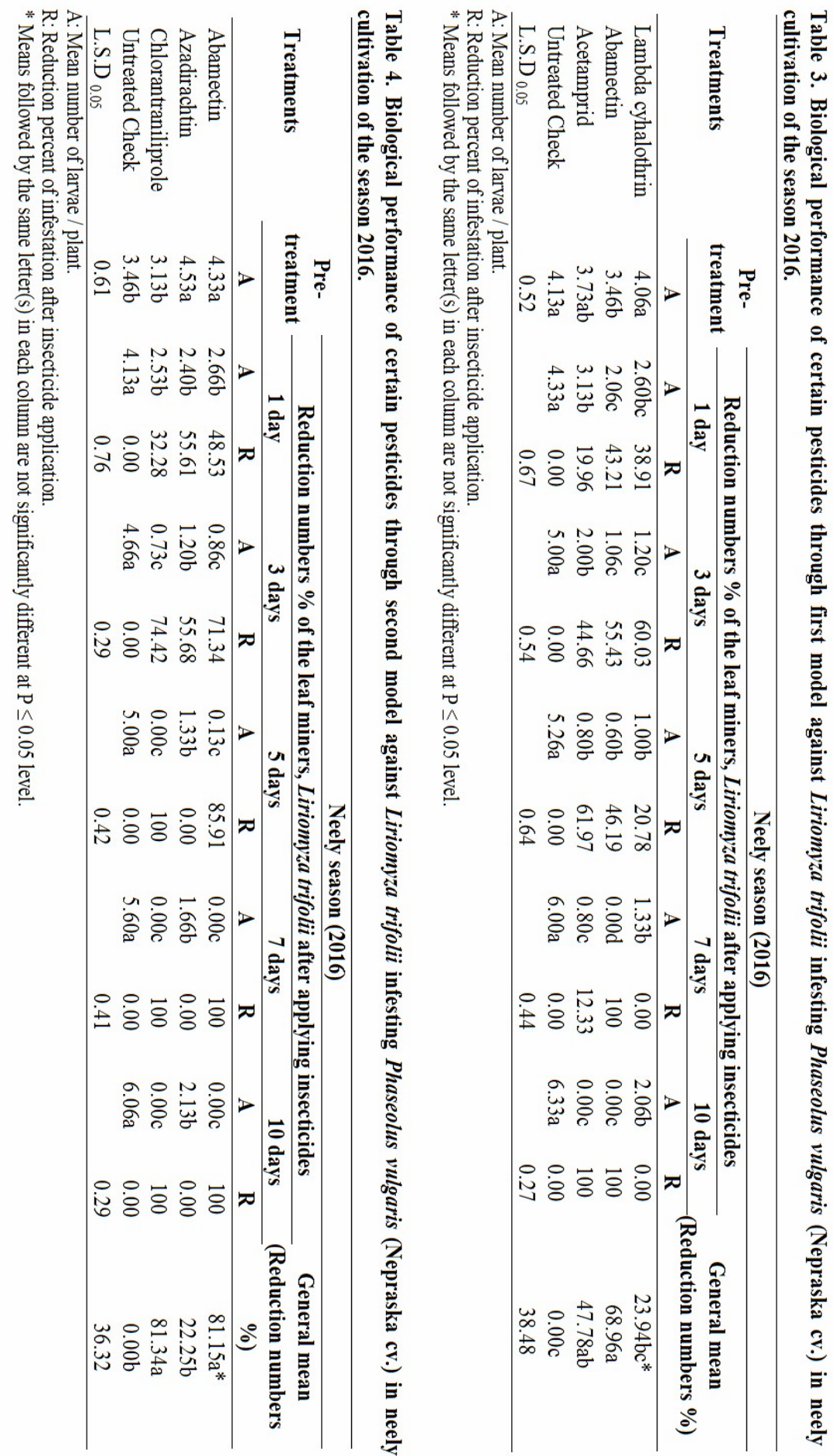




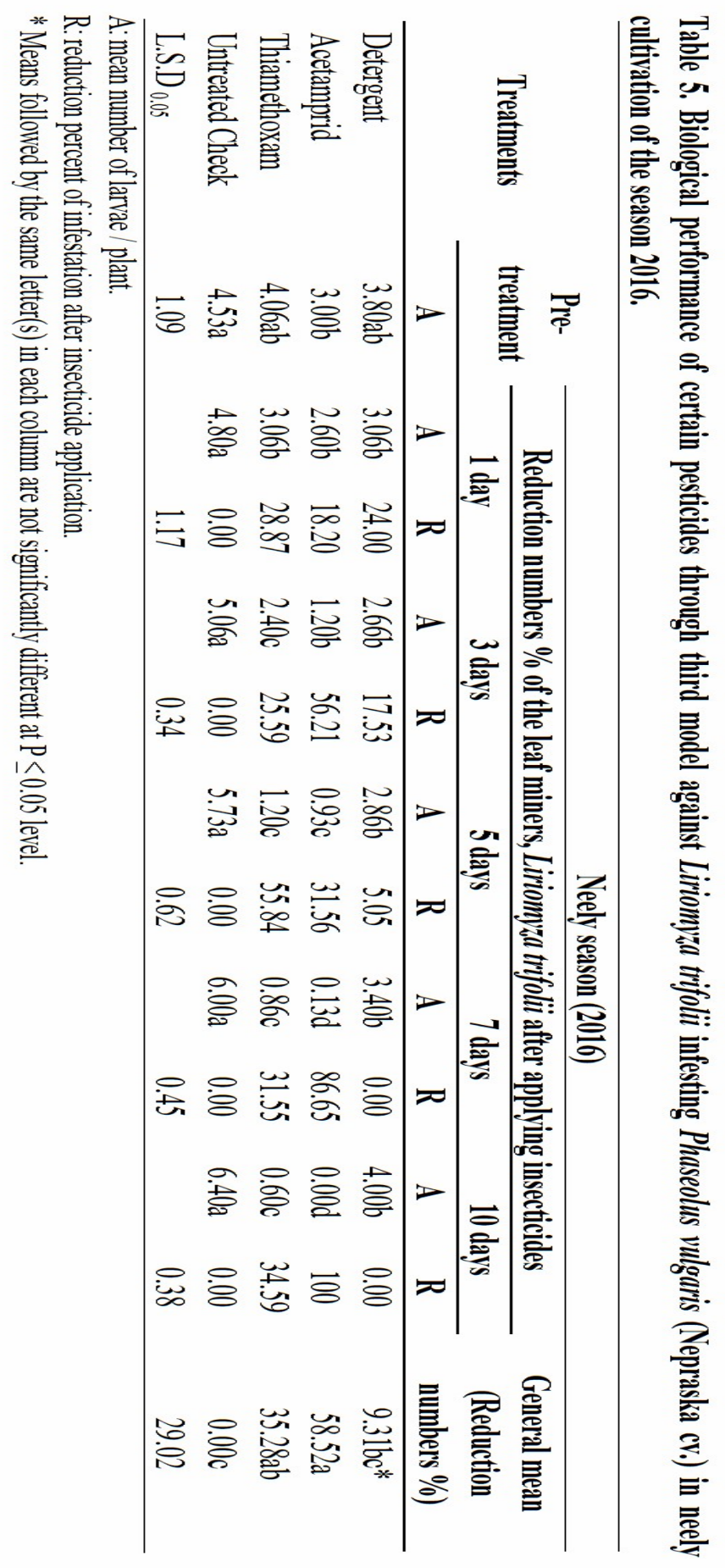


In general, the data in Table (4) showed that Chlorantraniliprole and Abamectin are superior treatments, and recorded the highest general means of results 81.34 and 81.15 of reduction percent, respectively. The less effective ones was the detergent with a reduction percentage of (9.31) Table, (4) and Fig. (4).

During the third season of 2016, the same trend has been followed as the highest general mean of reduction percentages (58.52) attained by Abamectin succeeded by (35.28) for Thiamethoxam and Detergent with (9.31) a reduction percentage, in respect, Table, (5) and Fig. (5).

However, it was observed that Models of certain pesticides exhibited very high potentials than those insecticides, which were used solely to combat the leaf miners pest. These results are in agreement with those of Abdel-Zaher (2005) who found that abamectin and spinosad showed almost the same trend of efficiency against $L$. trifolii infesting green bean.

\section{REFERENCES}

Abd El-Zaher, Mona A. 2005. Evaluation of certain insecticides for controlling leafminers in relation to their effect on yield components of the green beans (Phaseolus vulgaris). M.Sc. Thesis, Faculty of Agric., Saba Basha, Alexandria Univ., Egypt. 64pp.

Barakat, A. S. T. 2007. Integrated pest management for some economic pests infesting garden beans (Phaseolus vulgaris). M.Sc. Thesis, Faculty of Agric., Saba Basha, Alexandria Univ., Egypt. 93pp.

Bulletin of Agriculture statistics 2011. Summer, Neely crops, and fruit. Ministry of Agriculture and Land Reclamations, Giza, Egypt. (In Arabic).

Henderson, C. F. and E. W. Tilton 1955. Tests with acaricides against the brown wheat mite. J. Econ. Entomol., 48: 157161.
Johansen, N. S, m. T. Tao; K. O. Le and E. Nordhus 2003. Susceptibility of Liriomyza sativae (Deptera: Agromyzidae) larvae to some insecticides scheduled for their control in North Vietnam. Gronn Kunnskap 7: 157165.

Karel, A. K. and E. M. Mghogho 1985. Effect of insecticides and populations on the insect pests and yield common bean (Phaseolus vulgaris). J. Econ. Entomol., 78: 917921.

Kotb, Fawzia K. 2000. Field evaluation of certain Insecticides on faba bean leafminer Liriomyza trifolii (Diptera: Agromyzidae) and its ectoparasite Diglyphus isaea (Hymenoptera: Eulophidae). Adv. Agric. Res., 5(2): 1359-1370.

Leibee, G. L. 1988. Toxicity of abamectin to Liriomyza trifolii (Burgess) (Diptera: Agromyzidae). J. Economic Entomol., 81(2): 738-740.

Mesbah, H.A., E.H. Tayeb, A.M. Kordy, M.M.A. ElShershaby and N. H. El-Wakil.2016. Latent Effect of Two Formulated Botanical Fine Dusts on Agrotis ipsilon (Hufn.) Generation.Alex.Sci.Exch.37(2):221-230.

Mesbah, H. A. A., E. H. M. Tayeb, N.A. A. El-Sayed, M.B. A. El-Kady and A. A. A. Greira.2011. Biological Performance of Certain Botanical Fine Dusts, Ash and Sulfur Powders against the Rice Weevil Sitophilus oryzae (L.) (Coleoptera: Curculionidae). Alex. Sci. Exch. 32 (2): 173-181.

Parrella, M. P.; V. P. Jones; R. R. Youngman and L.M. Lebeck 1985. Effect of leaf mining and leaf stippling of Liriomyza spp. on photosynthetic rates of chrysanthemum. Ann. Entomol. Soci. America, 78: 90-93.

Steel, R. G. D. and J. H. Torrie 1981. Principles and procedures of statistic. A biometrical approach. 2nd Ed. McGraw. Hill Kogahusha Ltd. PP. 633. 


\section{الملخص العربي}

\section{الأداء البيولوجى لبعض الكيماويات الزراعية وبرنامج المكافحة ضد صانعات الاففاق فى الفاصوليا}

عبدالفتاح سيد عبدالكريم سعد ، حسن على عبدالحميد مصباح، أحمد محمد كردى ومدحت خميس

لكن فى الموسم الثانى 10 ـ ب كان أفــض المعــاملات

و أعلاها فى نسب الخفــ كــل مــن الكلــور انترنيلبرول \% و الأبامكتين س ا , ؟ج\%, . V

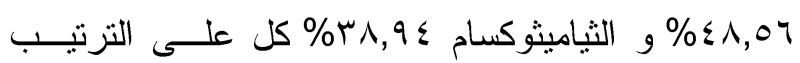
بدون وجود فروق معنوية بينما كان أقل المعاملات كل من

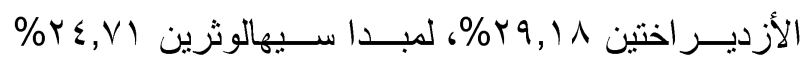
و الصابون السائل بr, \% كل على الترتيب بدون وجـود فروق معنوية.

لكن فى الموسم الثالث 1 ـ ب كانت أفضل المعــاملات فى نــسبة خفـض الإصـــابة الأبــامكتين منفــرداً يليــة الكلور انتزنيليبرول، الأسيتامبريد و الثيوميثوكسام فحين كانت أقــل المعــاملات فــى نــسبة خفــ الإصــــابة لمبــادا و الأزدير اختين و الصابون السائل.
أجريت التجربة الحالية فى مزرعة خاصـــة منزرعــة بمحصول الفاصويا صنف نبر اسكا أثنـــاء الموســـم النيلــى

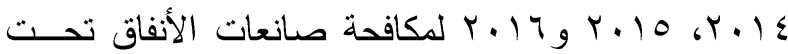
الظروف الحقلية فى منطقة النهضة بمحافظة الأســكندرية، حيث قيمت بعض المعاملات لركافحة صانعات الأنفاق التى تصيب محصول الفاصوليا فى مصر. أوضـــت النتــائج خـــلال الموســــ الأول ع ا ـ ب أن المتوسط العام لنسب خفض الإصـابة خلال فتــرة الفحــص حيث كان الكلور انترنيلبرول والأبامكتين أكثتر المعـاملات كفاءة ضد صـانعات الأنفاق فى الفاصـــوليا حيــث أعطــــ

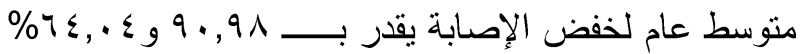
على الترتيب يليه الأسيتامبريد . 7, 700\%، و الثياميثوكـسام

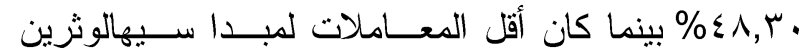

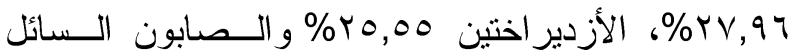

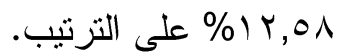

